\title{
Research on the Influence of Network Media on the Spread of Traditional Folk Music Culture
}

\author{
Jie Lin \\ Jiangxi Science \& Technology Normal University, Jiangxi Province, Nanchang, 330013
}

Keywords: National Music Culture; Online Media; Folk Music

\begin{abstract}
With the continuous development of Chinese network technology, more and more modern media continue to emerge, and our traditional national music culture is also affected by its transmission and the whole form of activity gradually by modern society and people's ideas imperceptibly, thus showing a new form and characteristics, such as the use of online media and the industrialization of access to the development of a new look. In reality, the network media plays an important role in the development of the traditional folk music culture in our country. Therefore, it is far-reaching influence on the development of the folk music culture in our country.
\end{abstract}

\section{Introduction}

Chinese folk music is the Chinese nation up and down five thousand years, the crystallization of ancestors from generation to generation art culture, but also our national characteristics can reflect our national culture and national spirit of the music culture. While China in the history of thousands of years of development, their own characteristics of the national music formed. In the moment, with the continuous development of Chinese network technology, China has entered the network media as the main feature of the development of information culture era. And the network media brought about by the spread of fast, diverse forms and broad space for development and other advantages gave the development of national music culture has brought challenges and opportunities, Chinese national music culture in the new era under the background of the vigorous development trend.

\section{The Advantages of the National Music Cultural Transmission under the Network Media Era}

National music as one of the manifestations of traditional Chinese culture in China, after thousands of years of cultural accumulation and change, it formed a Chinese music culture. It is Chinese thousands of years of history and culture and customs combined with hunger, it is also the existence of its existence to enhance our national art sentiment and artistic aesthetic sentiment at the same time also enriched our cultural connotation, and promotes our national culture towards healthy and sustainable direction. While folk music is rich in people's culture at the same time, itself as a form of culture has been spread [1].

Convenience. In the era of online media, the spread of national music culture in China also contains the characteristics of the network media itself, that is, in the context of the network media era, the spread of national music culture with the characteristics of the network media. Under the new era of national music culture to break the traditional folk music culture in time and space of imprisonment, now people no matter what time, what location, can be through the characteristics of online media, through a certain media, such as: Computers, mobile phones, etc., quickly and easily spread out, and its spread of the style is also a diversity, can be audio can also be the form of video. In the era of online media, people can quickly and easily spread the national music [2].

Diversity. National music as an important part of our national culture, naturally also served as Chinese national cultural heritage development and expansion of the important task. In the era of online media, the spread of national music is more convenient and timely, and this has an important role in the expansion of national music. In the context of the diversification and integration of 
cultural diversity in the world today, our national music should focus on its own cultural characteristics and increase its external expansion. At the same time, we should also pay attention to the national culture, development of. And our country as a multi-ethnic country, itself has a diversity of advantages. On the basis of traditional Chinese folk music culture into the multi-cultural, making our country's current national music presents a unique feature. For example, Chinese traditional national music "Butterfly Lovers", in the lessons of national traditions to learn the characteristics of Yue opera music on the basis of the integration into the modern singing techniques, and then through the re-processing and adaptation, which presents a different musical color [3].

\section{The Impact of the Network Media on the Traditional Folk Music Culture}

The Communication Form Fusion Online and Offline. Compared with the traditional way of the transmission of national music, the rise of online media has greatly expanded the way of transmission of national music. The media culture in the network media environment has an unprecedented opportunity. The advantage of network media technology is mainly to rely on modern information technology to obtain, in the Internet and the development of communication technology under the combined effect of the network media environment, the continuous dissemination of music channels, people enjoy the music art no longer need to buy audio products or to a variety of music activity site, only need to connect to the Internet, search keywords in the mobile terminal can get a lot of music information. The emergence of online media can effectively break the traditional restrictions on the spread of national music for the release of national music information provides a more convenient platform for the spread of national music and the promotion of efficiency will thus be fully promoted for the national music culture heritage and development the role played by no doubt. Therefore, the national music should face the current situation of the current lack of communication, the use of good network media platform for the cultural heritage of national music to open up more channels [4].

Pay More Attention to Brand Communication. How to expand the influence of national music in cross-cultural communication, and to better demonstrate the charm and connotation of national music, which is an important issue that musicians should think about. If we can focus on and strengthen the brand communication, create a series of national music brand, and cultivate the audience's brand awareness, should help in cross-cultural communication to better highlight the national music personality to convey the essence of national music. In the era of the rapid development of information media, the efficient and efficient communication function of the Internet can help the national music to shape the brand, expand the scope of communication and improve the influence of national music on the world cultural arena. Therefore, we should make full use of and enhance the brand communication, play the role of brand communication. It should be noted that the national music brand communication refers not only to the use of stars, celebrities to promote the spread of national music, but also can create some brand record companies, brand music production and dissemination of the company, the formation of omni-directional multi-dimensional communication.

Make Full Use of Media Integration of Three-Dimensional Communication. In the moment of media convergence, we should make full use of the media to carry out the rapid spread of the pursuit of national music transmission in all directions, three-dimensional. As a soundtrack is one of the most effective way to spread folk music: in the global film industry has become increasingly mature today, a large number of different cultural background of the film works to cultivate a large number of faithful audience, and in the fixed group of people through the film Soundtrack to spread the national music, is undoubtedly very targeted. As one of the ways of transmission of folk music, the soundtrack of music through the combination of music and film, not only to the viewer's thoughts, emotions to promote and catalyze the performance of the film's feelings and content, but also can use the fusion of Chinese and Western music to expand the performance of national music space, better performance of national music to convey the nationalization of the implication. 


\section{The Communication Strategy of National Music Culture under the Network Media Era}

Set Network Media as the Foundation and Achieve the National Spread of National Music. In the new era, the national music itself is a kind of carrier and it embodies the nation, the regional cultural thought, the way of life and the historical change, at the same time it is also in the daily life emotion exchange a kind of means. Therefore, any kind of national art cannot be separated from the characteristics of the nation. In the present society, Chinese national music culture in the process of communication continue to integrate into the diverse elements of the world, making it more effective dissemination of our national characteristics and spiritual outlook, to show the world. And the rise of the media and the media to give our national music culture to achieve this goal, and through the network media interaction and extensive, not only can make our national music not only has the characteristics and characteristics of the nation, but also able to through the network media for a wide range of communication. Promote our national music to absorb the essence of the rest of the world's music, and thus more in line with the needs of modern social development [5].

Through the Network Media to Innovate National Music Culture. Any kind of cultural form will be in the development process continue to draw on the essence of other cultures to promote their own development, in the process of continuous development and evolution of continuous innovation and progress. For the national music, but also follow the development of such a law. National music after thousands of years of cultural accumulation, the absorption from the various regions and the nation's cultural essence, and on its own basis, the music material to be innovative, thus creating a part of the unique works. As mentioned above, "Butterfly Lovers", "the new concubine drunk" and "all things", are in the preservation of the cultural charm of the nation on the basis of innovation, adaptation, thus showing the classic culture and modern culture integration unique charm. This product not only retains the national character of music, but also with the flavor of the times, in carrying forward our national culture at the same time, also passed a rich style of the times and humanities. More importantly, these folk music works in their own dissemination process also led to the spread of our national culture.

\section{Conclusion}

The development of national music culture in our country has achieved good results in contemporary times. It depends on the development of Chinese science and technology and the advancement of modern industry, and the positive view of the development of cultural industry in our country has an important positive influence on the development of national music culture. And the use of the richness of national music and cultural resources and cater to the development of modern society and people's needs, we need through the contemporary network media advantages and industrial development momentum, thus promoting the national music culture heritage and development.

\section{References}

[1] Guan Qingshan. Network media on the impact of traditional culture - to We-Chat as an example[J]. News Research Guide, 2015, 23: 49-50.

[2] Tian Jinliang. Talking about the influence of digital network media on traditional culture transmission[J]. Fine Arts Education Research, 2015, 23: $40+43$.

[3] Wang Chen. The influence of network media on the traditional folk music culture - Comment on "Chinese fine traditional art series: folk music" [J]. Youth journalists, 2016, 29: 113.

[4] Li Zijia. On the impact of online media on the spread of traditional culture [J] .Chinese Culture Forum, 2015, 09: 154-158

[5] Ning Wei. Mass media on the traditional folk culture spread analysis [J]. News Research Guide, 2016, 23: 261-262. 